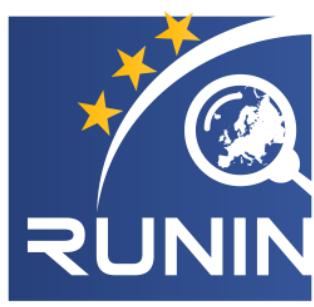

The Role of Universities in Innovation and Regional Development

\title{
Doctorate Holders' Transition to Industry: Networks as a Mechanlsm?
}

\section{Cases from Norway, Sweden and the UK}

WORKING PAPER 08/2019

DOI: $10.3990 / 4.2535-5686.2019 .08$

Available at https://runinproject.eu/results/working-paper-series/

\section{Elöise Germain-Alamartine}

Helix Competence Centre \& PIE, Linköping University (SE)

$\triangle$ loise.germain@liu.se

\section{Rhoda Ahoba-Sam}

Lincoln International Business School, University of Lincoln (UK)

$\triangle$ rahobasam@lincoln.ac.uk

\section{Saeed Moghadam-Saman}

Center for Innovation Research, University of Stavanger (NO)

$凶$ saeed.moghadamsaman@uis.no

\section{Gerwin Evers}

IKE Research Group, Department of Business and Management, Aalborg University (DK)

$\bowtie$ evers@business.aau.dk 


\section{Doctorate Holders' Transition to Industry: Networks as a Mechanism?

\section{Abstract}

The number of PhD graduates getting employed in industry in the EU has seen significant increase in the past decades. Although studies show generally that personal networks play an important role in the labour market process, little is known about the actual role networks play in the specific case of PhD graduates' transition from academia to industry. Consequently, this study aims to provide insight into the roles played by PhDs' networks in the job search after graduation. The study benefits from a social network perspective, in which extended intersectoral networks can be of central importance for doctorate holders' careers. Such extended networks are developed and managed within the broader context of university-industry collaborations to facilitate knowledge exchange between the two sectors. Accordingly, the study builds on the notion of 'overlapping internal labour markets', which refers to the emergence of career models based on university-industry links. Our data comprises 31 interviews with industry-employed STEM doctorate holders from Sweden, Norway and the UK. Our findings show that networks can play a facilitating role in matching the PhD's specific scientific expertise with labour market demands. Further, we elucidate country-specific patterns and characteristics of university-industry transition after PhD graduation, with regional career paths more (Scandinavia) or less (the UK) noticeable. Finally, the study has practical implications, in particular for doctoral students and PhD graduates related to their career orientation post-PhD.

Keywords: Doctorate holders, University-industry networks, Non-academic career, Overlapping internal labour markets

JEL: D85, J2, J62, I23 


\section{Doctorate Holders' Transition to Industry: Networks as a Mechanism?

\section{Contents}

Doctorate Holders' Transition to Industry...........................................................................

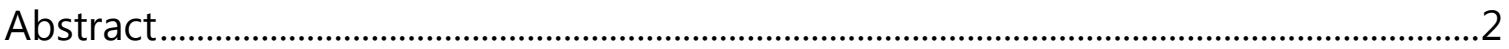

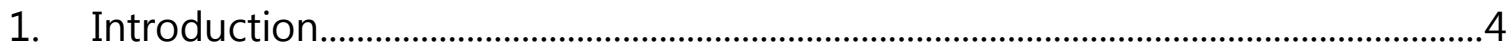

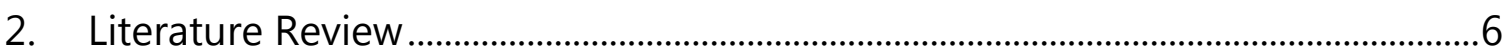

2.1. Challenges with employment opportunities for doctorate holders.....6

2.2. University-Industry networks and labour markets........................................7

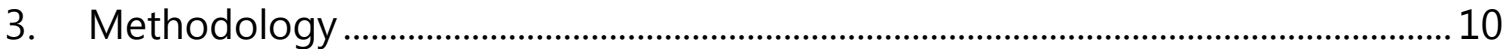

4. Empirical findings ............................................................................................... 13

4.1. Transition of PhDs to Industry .................................................................13

4.2. The role of networks in the 'academia-to-industry' transition ..............17

4.3. Personal networks....................................................................................... 17

4.4. Extended networks.................................................................................. 18

4.5. Outcome of network-aided transitions ......................................................19

4.6. Country specificities of network-aided transitions ....................................2

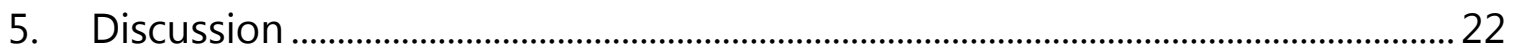

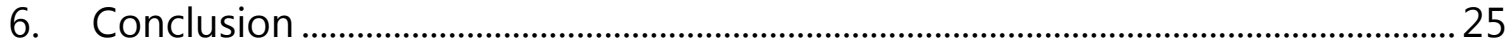

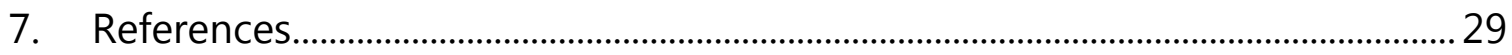

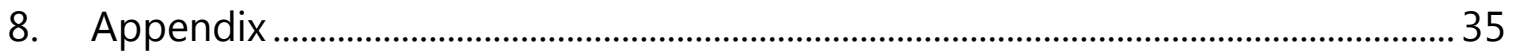

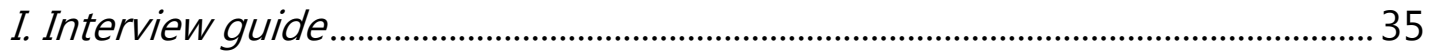

II. Perceived relevance of PhD studies to industry jobs ......................................... 37

Figures \& Tables

Figure 1 - Career and knowledge flows across academia-industry boundary...........9

Figure 2 - Overview of samples........................................................................................ 11

Figure 3 - Country-specific dominant patterns of transition of doctorate holders from academia into industry

Table 1 - Summary of network-aided transitions of doctorate holders from academia into industry. 


\section{Doctorate Holders' Transition to Industry: Networks as a Mechanism?

\section{Introduction}

The last few decades have seen a major increase in the number of PhDs annually trained by universities in OECD countries (OECD, 2016). This increase is however in strong contrast with the little growth in the number of available academic positions for which these graduates are traditionally trained (OECD, 2016; Larson, Ghaffarzadegan \& Xue 2014). Consequently, this phenomenon has led to more and more doctorate holders searching for jobs outside academia (Bloch et al., 2015). Although unemployment among doctorate holders is lower than in the general population (Auriol, 2010), an increasing share of them end up in positions for which they are overqualified or are outside their specific field of expertise (National Science Foundation, 2012).

The latter developments are often explained by the very specific scientific expertise developed during PhD training, which makes it difficult for graduates to find a job matching their education and skills outside academia (Maki \& Borkowski, 2006). In response, many scholars and policymakers have argued for devoting more attention to the development of generic skills in doctoral schools (Thune et al., 2012; Vitae, 2010; LERU, 2016). These developments have some potential to close the gap between the skills of PhDs and industry demand - though solely relying on this can limit the added value doctoral education has over master's education (Brennan, 1998; Hager, Holland \& Becker 2002; De La Harpe, Radloff and Wyber, 2000). Hence, employing different mechanisms for finding matching jobs outside academia can be useful to complement these kinds of initiatives.

In complement to research on the gap between skills and PhD's employability we argue that an in-depth understanding of the current processes of how PhD graduates obtain their employment is necessary. Existing knowledge is mostly 


\section{Doctorate Holders' Transition to Industry: Networks as a Mechanism?

focused on the destination of doctorate holders (Auriol, 2007; Drejer, Holm \& Østergaard, 2016) with little insight into the actual transition process between academia and industry (Manathunga, Pitt and Critchley 2009; Cruz-Castro and Sanz-Menendez 2005). Based on Granovetter's (1974) work, we are familiar with the importance of networks as an enabler of labour market matching processes by reducing the search costs and uncertainty involved. We therefore posit that network connections with industry actors might fulfil a similar important role in the job search of doctorate holders, especially since more and more PhD studies transcend academic and industrial settings (Wallgren \& Dahlgren, 2007; Thune, 2009), offering opportunities to develop these ties (Lam, 2007). Additionally, there is some research suggesting that PhDs in some cases could benefit from their supervisors' networks (Bøgelund, 2015).

While there are reasons to expect an important role of university-industry connections in the labour market matching process of $\mathrm{PhD}$ graduates, there is little research on the importance of these networks for PhD graduates entering industry. The increasing trend of PhD graduates moving to industry, either by preference or due to external factors such as labour market conditions, asks for a deeper understanding of the university-to-industry transition process. Hence, this study aims to explore the role university-industry networks play in the transition of PhD graduates to industry.

To provide insight into these roles, a qualitative research approach is adopted, in which 31 interviews of STEM doctorate holders from three different countries are analysed. The findings show that networks play an important role in increasing the quality of non-academic employment after graduation, by matching PhDs' specific scientific expertise with labour market demand. Additionally, there are country- 


\section{Doctorate Holders' Transition to Industry: Networks as a Mechanism?

specific patterns and characteristics of university-industry transitions after PhD graduation. These findings thus contribute to the literature on university-industry networks as well as literature on highly-educated workers' employment.

\section{Literature Review}

\subsection{Challenges with employment opportunities for doctorate holders}

With the democratization of higher education in the past century, there has been an increasing supply of highly-educated workers on the labour market (Auriol et al., 2013; OECD, 2016). This phenomenon goes along with the shift towards a knowledge-based economy in the European Union, and consequently increasing demand for such a workforce (Lisbon European Council, 2000). Simply, building of a knowledge-based economy invariably requires the availability of knowledgeable individuals. While the growth in absolute numbers of graduates trained annually is the largest on the undergraduate level, the relative growth is largest among the PhD graduates (OECD, 2016).

Doctorate holders are traditionally educated to conduct research in the area wherein they have become experts and teach their knowledge in higher education institutions (The Group of Eight, 2013). However, even though an increasing number of university students has created a larger demand for doctorate holders in the academic labour market, the growth in the number of doctoral students seems to have exceeded this demand. This imbalance in the demand and supply has led to a bottleneck in the progression of the academic careers of PhD holders (Andalib et al., 2018; Etmanski, Walters and Zarifa, 2017; Larson et al., 2014; Neumann \& Tan, 2011). 


\section{Doctorate Holders' Transition to Industry: Networks as a Mechanism?

Subsequently, there has been an increasing trend of doctorate holders leaving academia after graduation- and in most cases, to work in industry (Bloch, Graversen and Pedersen, 2015; Herrera \& Nieto, 2013). As doctorate holders are the most educated workforce (EHEA, 2018), one might assume that they have a privileged access to the industrial labour market in knowledge-based economies. However, mismatches are observed on this non-academic labour market for doctorate holders (Cedefop, 2016; Gaeta et al., 2016; Allen \& Van der Velden, 2001). Different types of mismatches are defined: skills mismatch, field-of-study mismatch, qualification mismatch (Corcoran and Faggian, 2017); even though over-education, or qualification mismatch, is the most discussed when it comes to university graduates (Green and McIntosh, 2007; McGuinness and Byrne, 2015; McGowan and Andrews, 2015).

Employment mismatches are important to solve because they imply a sub-optimal use of human capital leading to a decrease in productivity (McGowan and Andrews, 2015; 2017). This further implies that the problems doctorate holders face on the industrial labour market is not purely quantitative as is the case with the oversupply on the academic labour market, but more about realizing a suitable match between their qualifications and job offerings. These challenges therefore call for a closer look into what actually occurs at the university-industry interface.

\subsection{University-Industry networks and labour markets}

Career trajectories of doctorate holders have been extensively studied (Mangematin, 2000; Cañibano et al., 2018). Both internal factors, such as personal preferences, characteristics of the study and network opportunities (Mangematin, 2000; Jackson and Michelson, 2015); and external factors, such as the labour market 


\section{Doctorate Holders' Transition to Industry: Networks as a Mechanism?

demand (Bloch et al., 2015) have been reviewed. However, the actual means used by doctorate holders to find a job outside academia have received little attention. Though Granovetter (1974) stressed the importance of networks as a means to enable labour market matching processes, this knowledge has not been linked to the particular case of university-industry transition of $\mathrm{PhD}$ graduates.

In doctoral programs the transferable skill of developing networks has received increasing attention over time. This focus is especially beneficial since networking is a skill that can also be applied in a wider context than the specific scientific area wherein the doctoral student has become an expert and that can thereby increase their employability (Sinche et al., 2017; Kyvik \& Olsen, 2012). In addition, industry partners are increasingly involved in doctoral education, mostly by funding and hosting doctoral students through industrial PhD programmes (Roberts, 2018; Benito \& Romera, 2013; Wallgren and Dahlgren, 2005). This involvement of industry contributes towards fostering networks on the university-industry interface and arguably, play a role in facilitating the matching of the very specific $\mathrm{PhD}$ skills with the demands of industry. Simply, networks traversing the universityindustry interface may be key to enhancing the transition of doctorate holders to industry.

The transition from academia to industry could be viewed as a move from the academic internal labour market to an industrial internal labour market. Internal labour markets (ILM) are the institutional rules and procedures that govern the employment relationship within an organisation, such as recruitment, training, and the price of labour (Doeringer and Piore, 1971). ILM are hence distinguished from the external labour market (ELM) which is directly affected by macro-economic 


\section{Doctorate Holders' Transition to Industry: Networks as a Mechanism?

variables. However, ILM and ELM can be combined to form an extended internal labour market when, for example, recruitment channels deploy employees' networks to recruit additional workforce (Manwaring, 1984).

This tendency to rely on internal networks is in line with March's (1991) argument that organizations, when looking for new resources or markets, prefer to exploit internal resources they already have access to instead of exploring new ones. Lam (2007) studying employment at the university-industry interface took this concept a step further by arguing that ILMs' boundaries between two sets of organizations become blur when career and knowledge flows across them are supported through the creation of an overlapping space (Lam, 2007), i.e. the concept of overlapping internal labour markets (OILM, see figure 1).

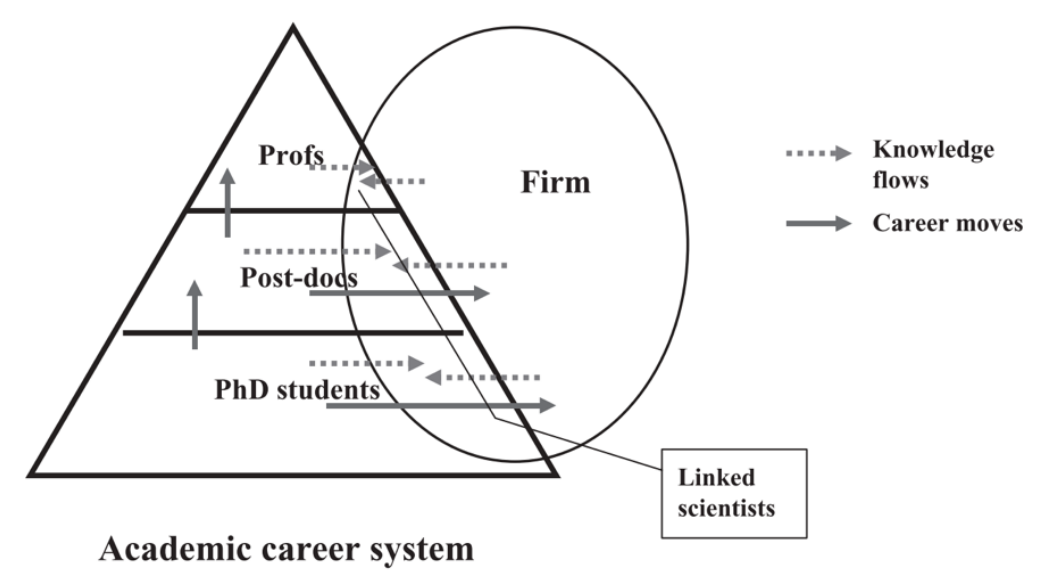

Figure 1 - Career and knowledge flows across academia-industry boundary. Source: Lam (2007, p.1011).

The OILM concept explains the forms of career models emerging from the industry-university R\&D collaborations, such as hybrid careers (Cañibano et al., 2018). 'Linked scientists' are researchers whose work roles and careers straddle firms and universities; entrepreneurial professors, post-doctoral researchers who play a major role in collaborative projects, and doctoral students who are jointly 


\section{Doctorate Holders' Transition to Industry: Networks as a Mechanism?

trained by universities and firms through varying arrangements. OILM can help firms in their selection and screening of the scientists involved for possible recruitment (Lam, 2007). It is the use of a pool of linked scientists by firms which leads to the formation of OILMs: "The idea behind this concept builds on that of a firm's internal labour market, and how it may be extended beyond the boundary of the firm following established recruitment channels and social networks" (Lam, 2007, p. 1011).

\section{Methodology}

In order to investigate the role university-industry networks play in the transition of PhD graduates to industry, we employed a multiple case study design. A qualitative approach based on semi-structured interviews with doctorate holders was adopted. This approach enabled a contextual understanding of the universityindustry transition and further offered in-depth insight into the social process of networking, and its complexities (Eisenhardt and Graebner, 2007; Yin, 1984). The prospects of obtaining rich data from varied sources and closeness of researchers to the data and its source presented further advantages for the chosen approach.

Interviews were conducted with 31 STEM PhD holders from six universities in three countries; the University of Lincoln and Loughborough University in the UK, University of Stavanger and University of Oslo in Norway, and Linköping University and KTH Royal Institute of Technology in Sweden (see figure 2). The focus on STEM graduates is based on the above average industry exposure these students experience during their studies (Perkmann et al., 2013). Convenience sampling was applied for selecting the countries and universities. Additionally, for each country, universities from both peripheral and central regions were included. Our sample 


\section{Doctorate Holders' Transition to Industry: Networks as a Mechanism?}

also included both indigenes and migrants of the selected countries. Hereby, the sample provides a comprehensive coverage of the employability dynamics of $\mathrm{PhD}$ graduates.

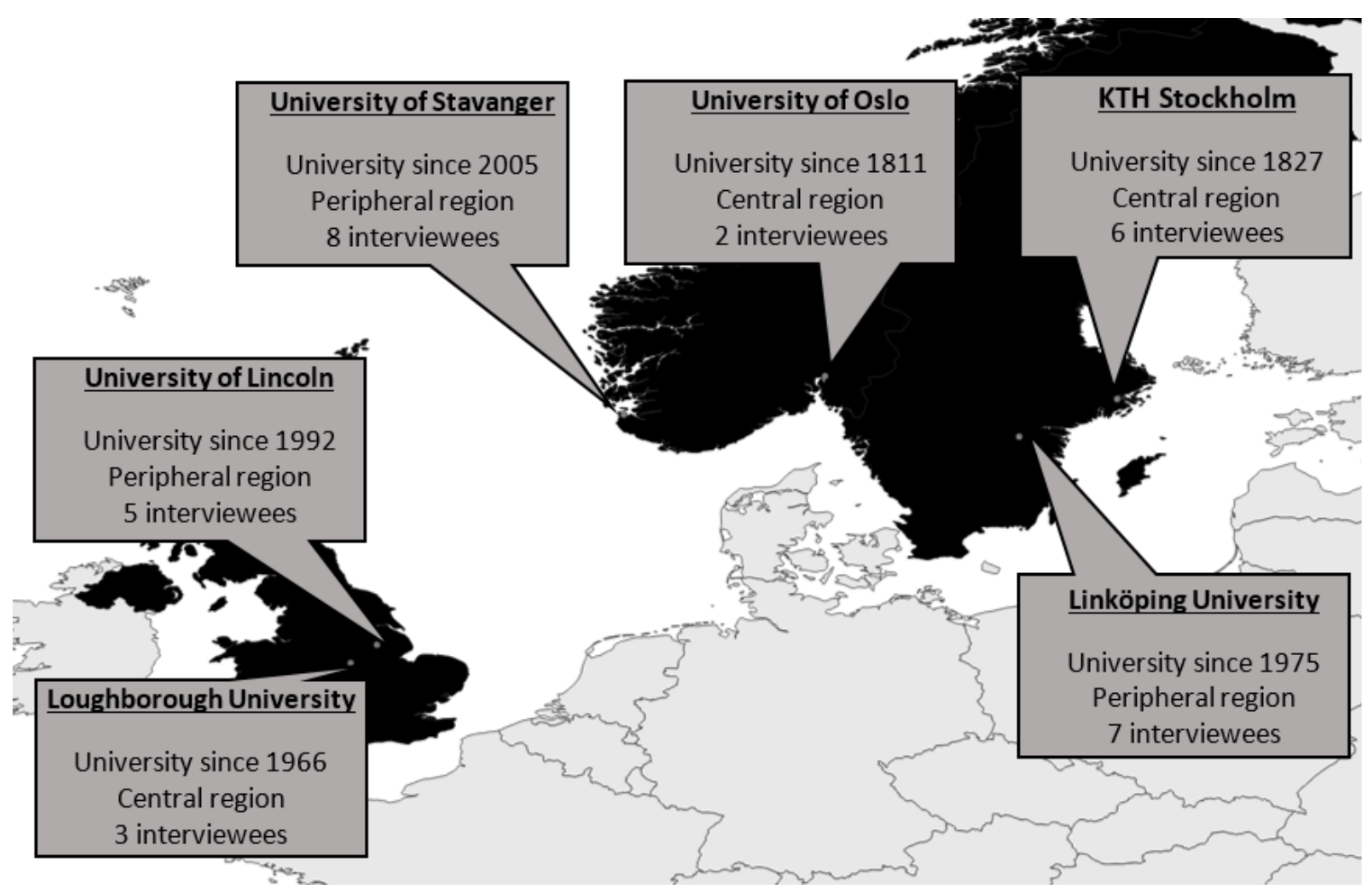

Figure 2 - Overview of samples.

All countries in our sample have displayed a rapid growth in the number of PhDs over the past decade (OECD, 2016). This growth could in part, be attributed to the Bologna processes aimed to foster the standardization and quality upgrading of doctoral education in the European higher education area (European Commission, n.d.). Also, the adoption of English as the main academic language has enabled the internationalization of doctoral education in the Nordic countries, with nearly all these written in English (Hultgren, Gregersen and Thøgersen, 2014). While the prescribed duration of doctoral education in Sweden is four years - a year longer than in the UK and Norway - usual delays and possible extensions due to teaching 


\section{Doctorate Holders' Transition to Industry: Networks as a Mechanism?

activities result in a PhD education of a similar duration in these countries as well (EHEA, n.d.).

In Sweden and Norway, the majority of $\mathrm{PhD}$ students are employed by the university and receive salaries based on collective bargaining agreements in place. However, the UK salaries for doctoral students are often based on external funding, leaving more room for heterogeneity between students and institutions, and results in lower relative average wages compared to the Nordic countries. The differences are also visible in status of doctoral students, in which supervisorstudent relationships tend to be more hierarchical in the UK than in the Nordic countries.

Contact details of the PhD graduates were retrieved through supervisors, university websites, and LinkedIn profiles. The PhD graduates were subsequently invited by email to participate in a 30-minute Skype or face-to-face interview in English. The semi-structured interviews were conducted with the help of an interview guide (see appendix I). The guide included a set of general topics and several specific questions to assure a comprehensive coverage of the topic. The recordings of these interviews were subsequently transcribed. The analysis consisted of two steps: first, the interviews were summarized into a table to provide a systematic insight in the findings for several areas of interest. Here, individual transcripts were analysed. Next, the individual insights were synthesized to obtain an overall understanding of the data collected. 


\section{Doctorate Holders' Transition to Industry: Networks as a Mechanism?

\section{Emplrical findings}

\subsection{Transition of PhDs to Industry}

The data collected illustrates that a myriad of factors influence the transition of doctorate holders from academia into industry jobs. Most commonly, the industry destination was observed to contrast with doctorands' a priori career goal of remaining in academia. Only 14 out of the 31 informants wanted to be in industry from the start - with 6 of them being from the Norwegian sample - and 2 of them undecided. Notably, only 1 person (out of 10 informants) from the Norwegian sample wanted to remain in academia from the onset of the $\mathrm{PhD}$. Generally, this redirection of career trajectory was attributed to factors such as a lack of career prospects in academia, instability/insecurities involved in working on contract basis, and family situation. As explained by an informant from our Norwegian sample,

'[My supervisor] suggested me to stay at university longer based on yearly contract. For me, it was very tough because at that time I needed to have a very safe stay in the country because I had a family. I wanted to be really safe in the country. I wanted to have work permit here. The yearly contract was not for me to convince me to stay at university' (NOR-5)

The majority of our interviewees moved to industry directly after graduation, with many of them acquiring the position before their graduation. Other PhDs stayed in junior positions in academia before making the move to industry. Some of our interviewees even turned down an academic job offer to pursue one in industry these interviewees had lost interest in an academic career after the first-hand experience during their PhD. Interviewee UK-8 explained her desire to leave academia as follows: 


\section{Doctorate Holders' Transition to Industry: Networks as a Mechanism?

'They offered me [a position], because they wanted me to stay. I just wanted to go... I wanted to leave... I wanted to get out of there'

Most of the PhDs in Norway and Sweden were familiar with their respective regions before entering their PhD position, while majority of the interviewees from the UK migrated for study purposes. Evidently, the UK informants were more open in their search for admission into PhD programmes. Interviewee NOR-10 explained how his existent network in his region helped him land his PhD position;

II was actually based here when the position was advertised and I knew one of the people from the companies who were sponsoring the [research centre]. I actually came to know about the position through him. He happened to be one of the interviewers from my previous company where I was working in Stavanger I got the job in that previous company because of him, then he moved out and then we met and then he suggested that the sector has been just established and they're going to post position for many PhDs.'

Considering the motivations to study in the various institutions, two main strains of interviewees are apparent: first, those interested in studying in a particular university and second, those who were more interested in a field of research rather than the university which offered it, as emphasized by UK-2 - 'I would be lying to say it was the place. .... liked the project, it sounded cool and I was accepted'. Specifically, for those interviewees who knew from the start that they would opt for an industry career post $\mathrm{PhD}$, the location of the university appeared to be important - if the industries of interest were accessible.

The search for an industry job resulted in half of the informants (15 out of 31) leaving the region (or country) where they obtained their doctorates. Also, we see this distinction in mobility, with graduates in Scandinavia more likely to stay in the region, while most graduates in the UK moved to obtain employment. Although these findings are in line with the knowledge that labour mobility in the UK is 


\section{Doctorate Holders' Transition to Industry: Networks as a Mechanism?

higher than in Scandinavia, the differences could also be explained by the fact that the UK PhD graduates had already moved before - which is understood to increase the likelihood of moving again. The UK graduates themselves mainly ascribed their reason for moving to a lack of employment opportunities in the region of study. Here, a regional career path was not visible, and interviewees were more inclined to fall back on networks (being industry or academia) built prior, during or after their PhD. This was highlighted by UK-4,

'To be honest, that time I did not get any opportunity in my field and there was no vacancy actually. But, if I got any opportunity during that time .... because I was living there for four years we had some kind of social relationship with people and also we know lots of people there. It would have been good for us to stay there... I did my master from P. before, so I already knew the place and that's why I came to [the same place] after my Ph.D.'

An explanation for the absence of relevant local network connections could be that the development of relevant professional network is a long-term process, and hard to develop when starting from scratch as a newcomer to the region. The

Sweden sample was characterized by nearly equal proportions of persons who left or stayed in their respective regions. With a very high exposure to industry during the $\mathrm{PhD}$, the tendency was to access these industry contacts for their transition, as in the case of SWE-9:

'My first job in industry] was very tightly connected to my PhD project. The company I work for now, they were the main sponsor of that project. But I was not an industrial PhD, so I was employed completely by the university. [...] basically, they asked me if I wanted to work there [after my PhD].'

To that extent, a regional career path is visible. Additionally, the majority of informants were found to likely transition into industry after some time of working as a post-doc in academia. In our Norway sample, a regional academic path was prominent. Pre-PhD industry networks seemed to be highly influential on the 


\section{Doctorate Holders' Transition to Industry: Networks as a Mechanism?

career moves and nearly all interviewees remained in the regions of their $\mathrm{PhD}$ education. However, also personal factors related to family conditions were driving their mobility.

All informants ascribed some relevance of their PhD education to the industry they were working in. This implies that the various disciplines of their research were of significance to the firms they were employed in. However, their jobs did not necessarily always match their qualifications. A section of them were carrying out jobs that were within their research fields for which a PhD degree was a requirement. A second group, though working in similar fields to the PhD studies, explained that those jobs could equally have been executed by persons with a master's degree in the same field. Notably, a PhD was not always a necessary requirement for a job in industry. Another set were engaged in related research industries where they applied similar theories, methodologies and tools as used during their $\mathrm{PhD}$, however to very different concepts and contexts. One more set attributed the relevance of having a $\mathrm{PhD}$ to the skills they acquired and not necessarily the subject they studied. This implied that even in unrelated fields, some generic skills acquired during the $\mathrm{PhD}$ proved useful ${ }^{1}$. This was emphasized for example in the case of SWE-5:

'... What I am working on right now is very different from the application I was working on at KTH but since, I did mathematics, applied mathematics, basically, I'm using those skills that I learned during my Ph.D. When I do the research and present new algorithms and so on. So the application is different, but the background and the basics are the same.'

${ }^{1}$ See appendix II for details of perceived relevance of industry jobs to PhD studies. 


\section{Doctorate Holders' Transition to Industry: Networks as a Mechanism?

\subsection{The role of networks in the 'academia-to-industry' transition}

In the process of moving to industry, networks seemed to play an important role. The involvement or not of network ties in the transition to industry could be attributed to the disposition of the doctorate holder at the time of job search. With the end of their PhD studies imminent, the student would begin to explore various life paths after obtaining a doctorate. If they wanted a job in academia, they would first explore their options there; if not, they would look elsewhere. It was apparent from our data that the search for a job position was mostly directed by their area of study. If positions were available, 'interesting and provided a 'good overlap' to their interests they would take advantage of them. An interplay between the personal network of informants and a more extended network of their associates was apparent. Interviewee NOR-2 explained this;

'Actually when we've visit these conferences and sometimes it was professor who was visiting-- It was not me. [...] He presented my work and then they were saying that they're also dealing with the same problem. Then he gave me their numbers and I contacted them. [...] it was actually a mixture of my network together with professor's network.'

\subsection{Personal networks}

The personal network refers to links that were individually known to informants for transitioning into industry without necessarily tapping into the network of another person in their wider network. This includes networks initiated during the $\mathrm{PhD}$ as well as network ties that were established during prior work experience. In some instances, relying on personal networks was evident as in the following instance;

'In that sense I had a collaboration with them but I applied [for the job]. I didn't really apply for a job. I guess, found a person, who I started talking to and then, they ended up offering me a job.'

(SWE-07) 


\section{Doctorate Holders' Transition to Industry: Networks as a Mechanism?

This was observed both in the case of collaborative (research carried out with industry partners) and non-collaborative doctoral studies. These personal network connections were seen to consist of either industry or academic contacts. Apart from existing connections (academia or industry), the graduates were also observed to have initiated new connections that led to employment in industry. These links extended beyond the period of PhD education to include links such as colleagues from previous education: as UK-5 put it:

'I had a colleague from London South Bank, where I did my masters, who was the technical manager in that area. When I was in the UK looking for a job opportunity, I contacted my colleagues, and she gave me the opportunity.'

\subsection{Extended networks}

Additionally, we isolate an external network of wider university and industry connections who play unique roles in the graduates' industry employability. For instance, this was mostly evident when a personal connection of the graduate referred them to another person to increase their job prospects. Some PhD graduates were however reluctant in using the network of fellow academics and preferred to rely on their own network in their job search. As exemplified in the case of NOR-4,

I would not use it [the network built during PhD] for finding jobs but it will be more on the technical side [for exchange of knowledge]'

As evident from our data, academic supervisors or principal investigators rarely played a direct or active role in the transition to industry. The participation of $\mathrm{PhD}$ supervisors was peripheral and often relegated to the role of a reference person in the recruitment process. Only in two cases did a collaboration initiated by a principal investigator lead to the recruitment of his PhD student as exemplified, '....he went to my university... he told my supervisor and then my supervisor got me 


\section{Doctorate Holders' Transition to Industry: Networks as a Mechanism?

to go for their interview (UK-9). In the other cases where help had been sought from supervisors to aid a transition, the opportunities within the PIs network were seemingly non-existent.

Further, none of our informants reported any specific help from their universities in transitioning into an industry job. Belonging to a research group which had some collaborations with industry however provided an exposure to some researchrelevant industries, as seen in the following quote from SWE-12:

'Interviewee) On the paper, [my PhD] was in coordination with Saab, I had quite some things with them to do, from my personal I think I would say nothing of what I've been studying has been applied (laughs) so there must be a total failure somewhere but yes I mean it was one of those [...] national research program so normally it was partnership but...

(Researcher) So you worked with people at Saab but not the ones that were involved in your recruitment?

(Interviewee) No I didn't work with them, I worked with two guys maybe, but not that much. But I've been encountering later but we never really worked together but they all know what I've been doing.'

On the wider university scale, various platforms also provided an opportunity to meet industry employers. In the case of one interviewee, it was an event organised by a student association which was decisive in starting the transition to industry: 'And so it was very informal. I happened to meet an HR person at a dinner about a year earlier' (SWE-7).

\subsection{Outcome of network-aided transitions}

In some of the instances where networks were the mechanism through which the transition to industry has occurred, positions were 'created' for the doctorate holders. In this way networks did not just facilitate the transition to industry, but also influenced the outcome of the process. 


\section{Doctorate Holders' Transition to Industry: Networks as a Mechanism?

'The position was there [but] it was not meant to be a position for my scope. When I applied, then they felt that they also need to have someone with my background and my experience, that they made some adjustment in the requirements of the vacant position'(NOR-5)

Most of the PhDs maintained their academic network when transitioning to industry. In some cases, this was more of a social nature, while in other cases there was also academic content in the form of part-time academic positions and/or copublication relationships. This academic involvement might for some of the PhDs be motivated by increasing the chances of moving back to academia in a later stage of their career.

Overall, we observed heterogeneity in both the kind of network ties and their importance for the transition of PhD graduates to industry. Personal networks were more prominent in the university-industry transition than were extended networks. Individuals took advantage of their existing networks or forged new ties in their transition to industry. Depending on the particular interests of the $\mathrm{PhD}$ graduate, both explorative and exploitative tendencies were employed to aid their job search. The various channels that emerged from our analysis are summarized in table 1 .

Table 1 - Summary of network-aided transitions of doctorate holders from academia into industry.

\begin{tabular}{lll}
\hline & Personal networks & Extended networks \\
\hline New ties & Individual's search disposition & PI's networks \\
& and preferences: & Research group links \\
& $-\quad$ Exploration & Wider university links \\
& $-\quad$ Exploitation & Industry links \\
\multirow{5}{*}{ Existing ties } & Formed prior, during or after & \\
& PhD education & \\
\hline
\end{tabular}




\section{Doctorate Holders' Transition to Industry: Networks as a Mechanism?

\subsection{Country specificities of network-aided transitions}

Based on our data, we can distinguish country-specific dominant patterns, in terms as characteristics and tendencies of university-to-industry career transition, as follows:

- In Sweden, having a post-doctoral experience is quite common; and PhDs' academic networks seemed to drive the academic career vertically. However, a prolonged stay in academia weakened the ties to the pre-PhD industry networks of $\mathrm{PhD}$ candidates. There is overall a relatively high exposure to industry during the $\mathrm{PhD}$, and individuals' post-PhD industry networks are mostly different from their pre-PhD industry networks. Finally, regional career paths are quite noticeable.

- In the UK, a post-doctoral experience is seen more as an option than as a preference. Individuals' academic and industrial networks change markedly before, during and after the $\mathrm{PhD}$ due to a quite high geographical mobility. When it happens, a high exposure to industry during PhD has a significant impact on transferable skills, and the existence of a firm-centered OILM during PhD education often functions as a network mechanism for post$\mathrm{PhD}$ careers.

- In Norway, choosing a post-doctoral contract is less common than in Sweden. PhDs' industrial networks built prior to doctoral studies seem have an important influence on their career moves. Working in industry after master's studies, and before PhD studies, is quite common. However, exposure to industry during PhD does not seem to be that high. Regional career paths are noticeable. Nevertheless, worth highlighting is the fact that, most of the PhDs in the Norwegian sample may have been affected by the 


\section{Doctorate Holders' Transition to Industry: Networks as a Mechanism?}

downturn in the oil industry some years back, and may have affected the observed transition model - in the sense of the PhD graduates have worked in industry prior to the $\mathrm{PhD}$ and choosing further studies when they were affected by job loss. Finally, the existence of a firm-centred OILM prior to the $\mathrm{PhD}$ often functions as a network mechanism for post-PhD careers.

Figure 3 schematically summarizes the above-mentioned country-specific trends in a model based on Lam's (2007) OILM framework (see Figure 1).

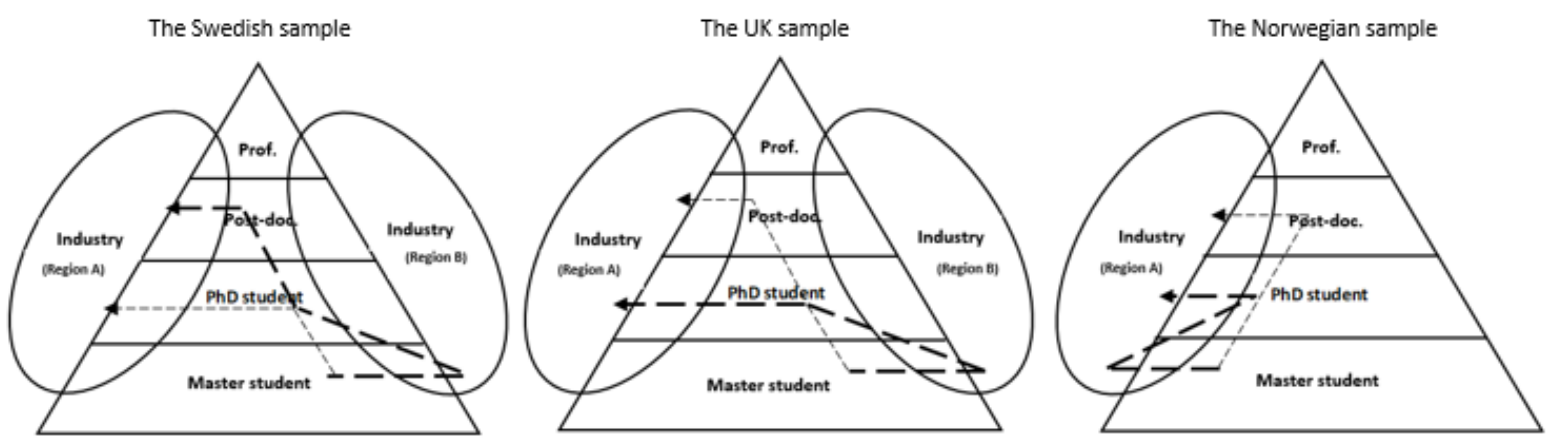

Figure 3 - Country-specific dominant patterns of transition of doctorate holders from academia into industry

\section{Discussion}

From our observations, it is evident that different types of networks come to play in the industry employability of $\mathrm{PhD}$ graduates. Firstly, we recognize that the personal network connections of the PhD graduates played an important role, both in the case of collaborative and non-collaborative PhDs. By personal network, we refer to the graduates' own links that directlyled to employment in industry. These personal network connections were observed to consist of either industry or academic contacts with whom the graduate had existing connections prior to job search and extended beyond the period of PhD education (e.g. where previous colleagues from master's programs played a role in landing an employment). 


\section{Doctorate Holders' Transition to Industry: Networks as a Mechanism?

Apart from their pre-existing connections, the graduates were also observed to initiate new connections that led to employment in industry. Contrary to Mangematin's (2000) observation that PhDs generally do not possess the requisite networks or experience to explore non-academic options, we can assert that certain $\mathrm{PhD}$ graduates not only possess the requisite networks, but also initiate the needed connections and may actually prefer relying on their personal networks. Secondly, we isolate an external network of wider university and industry connections who could also play unique roles in industry employability of the graduates. In either case, the network tie could be a new or an existing connection in the graduate's network.

According to literature (e.g. Lam, 2007; 2011) three main types of academics exist at the U-I interface. These so-called 'linked academics' bear the identities of professors, post-docs and PhD students. While professors are conceptualised as the focal points of these U-I linkages, post-docs and doctoral students are considered the 'growing' and 'hybrid' categories of linked scientists. Even though professors play a central role in U-I linkages, the evidence collected suggests that their influence in the employability of the $\mathrm{PhD}$ graduates in industry is peripheral. Accordingly, it has been reported that professors - or principal investigators (PIs) often lack the needed networks in industry that could contribute to industry employment of their students. Indeed, they usually lack knowledge of career opportunities that may exist in industry (Golde, 2005). As evidenced from the data collected, their role in many cases was only relegated to the provision of references for their students' job applications.

It has been suggested that the increasing blurring of industry - university boundaries through collaborations (Thune, 2009; Roberts, 2018; Benito \& Romera, 


\section{Doctorate Holders' Transition to Industry: Networks as a Mechanism?

2013) offers a higher probability of job opportunities of PhDs in industry. Particularly, it is projected that university-industry collaborations would serve as a platform for selection, screening and subsequent recruitment of PhD graduates into firms (Lam, 2007). In that case, it would be expected that PhD graduates who were involved in collaborative projects (for their PhD studies) would record a higher ease to industry employment with PI-facilitated employment. This is however not explicitly observed from our evidence. For example, both groups of $\mathrm{PhD}$ graduates (from non-collaborative and collaborative) did not experience PI-facilitated employment.

According to Hancock and Walsh (2014), doing a PhD may mean forgoing other training opportunities relevant for non-academic jobs. In line with their assertion, we observed that in many cases the $\mathrm{PhD}$ qualifications are indeed more fieldspecific than industry jobs would require. Industry opportunities tend to assume a not-too-specific nature and do not necessarily call for very specialized scientists. We project that this imposes a mismatch that the extended U-I networks cannot always address and solve. Contrary to Hancock and Walsh's observation, though, we also find that the $\mathrm{PhD}$ education equips $\mathrm{PhD}$ graduates with other industryrelevant skills. When they get employed in industry, the edge they present to their employers is not necessarily the merits of a field-specific PhD qualification but a wider set of qualifications and skills, such as those related to management roles. In cases where hiring is based on the field-specific expertise of the graduates, the creation of new roles is observed. It can also be said that PhD degrees are often not a 'necessity' for industry work (see Appendix II), but are sometimes useful for work progression once hired, or might lead to the creation of new roles and positions in companies. 


\section{Doctorate Holders' Transition to Industry: Networks as a Mechanism?

The dynamic nature of job type orientation of doctoral candidates needs to be considered too. It has been reported that individuals who pursue a PhD have a taste for science and those who lose interest for research during the PhDs are more likely to pursue industry jobs (Sauermann and Roach, 2012; Hayter and Parker, 2019). While this change in career preference is evident from our study, we perceive that the destination of $\mathrm{PhD}$ graduates (i.e. industry or academia) is also subject to an opportunity 'exploration' and 'exploitation' mode of PhD holders. With the increasingly low likelihood of acquiring academic jobs, non-academic destinations do not simply become a preferred option but a necessary option for the PhD holder. In such cases the absence of existing networks to exploit - as the candidate's current networks might be mainly of academic nature - leads to exploration of new opportunities by initiating the establishment of networks with industry.

\section{Conclusion}

The concept of Overlapping Internal Labour Markets (OILM) was employed to explain the way doctoral graduates benefit from the extended networks of academics around them in making the career transition to industry. The findings from the interviews demonstrate that OILMs, when seen from the academic side of the network, play a rather peripheral role in facilitating the career transition of doctoral graduates. On the other hand, when considering the industry side of the network, OILMs in the form of connection with industry individuals known to doctoral graduates from their networks established during or before doctoral studies, do play a positive role in their transition to industry. What our study shows, therefore, is that personal networks of doctoral graduates intertwine with university-industry OILMs which can facilitate a move to industry 


\section{Doctorate Holders' Transition to Industry: Networks as a Mechanism?

Nevertheless, the findings of our study indicate that contextual specifics make a difference regarding the extent to which personal networks of doctoral graduates overshadow the OILMs. In a context like the UK-based cases, where the mobility of doctoral applicants and graduates is very high, the personal networks are sparse, making it less probable that such networks intertwine with OILMs around the doctorate holders' alma mater university. On the other hand, in a context like the cases based in Norway, the geographical closeness of pre-PhD and through-PhD personal and professional networks of doctorate holders helped them considerably to intertwine those networks with the OILMs, which were in fact mainly formed between their pre-PhD employers and their alma mater university. The case of Swedish interviewees, then, implies at personal and professional networks of doctoral candidates becoming updated during doctoral and postdoctoral studies, in which an OILM is formed that later is used by doctoral graduates for transition to industry.

Overall, there seems to be a meaningful level of relation between doctoral graduates' history of geographical mobility and the extent of exploitation of OILMs by them. It can be observed from our data that, the less the geographical mobility during the pre-PhD and post-PhD periods, the more the likelihood of benefiting from the intertwining of personal networks with the OILMs. Nevertheless, the importance of regional job market characteristics in conditioning the above statement should not be overlooked. As our Norwegian cases show, the possibility of formation of OILMs between university and industry is largely influenced by the industrial structure of the region where the university is located. These observations corroborate the findings in the literature on job (mis)match and spatial mobility, which posit that "geographical characteristics are likely to affect 


\section{Doctorate Holders' Transition to Industry: Networks as a Mechanism?

labour market outcomes such as match or over-education" (Iammarino and Marinelli, 2015, p. 2). In line with this, we conclude that university-industry OILMs can play a facilitating role in the transition of doctoral graduates to industry when graduates actively explore such spaces through their personal networks, but this in itself is contingent to the regional industrial characteristics, as these characteristics significantly influence the intensity of OILMs, and hence the OILMs' potential usefulness for career search and match.

This paper contributes to the literature on university graduates' career, but more specifically doctorate holders' career, as well as the role of social (professional) networks in job match making. Using the concept of OILMs made it possible for us to combine and establish a link between the above-mentioned strands in the literature. The findings of our study are aligned with Thune's (2009) proposition, who based on a review of empirical literature on graduate student-industry collaboration, asserts that more than collaborative experiences during $\mathrm{PhD}$ education, it is individual characteristics of doctoral graduates that can explain differences in their career trajectories. In a similar vein, our analysis made it clear that the OILMs, while providing a "structure" for doctoral candidates and graduates for exploring career transition opportunities, do rely on the "agency" of these job seekers to actualize and deliver their potential. In other words, the activation of personal networks by doctorands, and intertwining them with the networks taking shape within OILMs, appears to be the key to the well-functioning of universityindustry extended networks (extended internal labour markets) in terms of facilitating a career transition. At the same time, however, the contextual factors such as the industrial structure of the region where the universities are located, and the form of level of interaction between university and industry, influence the 


\section{Doctorate Holders' Transition to Industry: Networks as a Mechanism?

OILMs potential for enriching doctorands' (agents') individual networking initiatives.

A practical implication from the results gained in this paper is directed at doctoral researchers and graduates who seek to pursue a career in industry after doctoral education. As indicated above, there seems to be a significant role attached to the agency, or in other words, deliberate and conscious initiative of doctorands in activating the potential of university-industry extended networks (OILMs). Hence, it is crucial for doctorands to actively search and establish linkages between their personal networks and the U-I networks surrounding them in pursuit of an academe-to-industry career transition. Also, a policy implication can be drawn from our observations, and that concerns the collaborative doctoral programmes, i.e. doctoral programmes which include university-industry collaboration. For such programmes to deliver a better career-relevant results, it seems to be of crucial importance to design and structure the collaboration terms in such a way that maximizes the networking opportunities for doctorands. Our observations showed that the firm side of OILMs harbours a more influential part in providing careerrelevant networking opportunities compared to the academic side.

The findings of our study need to be understood with its limitations in mind. The university-industry OILMs are not formed solely around the STEM fields, even though the STEM fields might be the area where OILMs take shape more clearly. Hence, further research can explore whether our findings apply for the case of doctoral graduates from other academic disciplines, such as law, business administration, industrial management and alike. Furthermore, our cases were limited to a sample of doctoral graduates from a few universities in the UK, Sweden and Norway. The importance and the functioning of personal networks can change 


\section{Doctorate Holders' Transition to Industry: Networks as a Mechanism?

based on the size of informal networks (cf. Calvó-Armengol and Zenou, 2005) and their influence in the job search across different countries and cultures. Accordingly, further research is needed to investigate the relevance of OILMs for the job transition of doctorate holders from other disciplinary as well as geographical and cultural contexts.

\section{References}

Allen, J., \& van der Velden, R. (2001). Educational mismatches versus skill mismatches: Effects on wages, job satisfaction, and on-the-job search. Oxford Economic Papers, 53(3), 434-452. https://doi.org/10.1093/oep/53.3.434

Andalib, M. A., Ghaffarzadegan, N., \& Larson, R. C. (2018). The Postdoc Queue: A Labour Force in Waiting. Systems Research and Behavioral Science, 35(6), 675-686. https://doi.org/10.1002/sres.2510

Auriol, L. (2007). Labour Market Characteristics and International Mobility of Doctorate Holders: Results for seven countries. OECD Science, Technology and Industry Working Papers.

Auriol, L. (2010). Careers of Doctorate Holders: Employment and Mobility Patterns. OECD Science, Technology and Industry Working Papers.

Auriol, L., Misu, M., \& Freeman, R. A. (2013). Careers of Doctorate Holders: Analysis of Labour Market and Mobility Indicators (OECD Science, Technology and Industry Working Papers 2013/04 No. 4).

Benito, M., \& Romera, R. (2013). How to boost the PHD labour market?: facts from the PHD system side.

Bloch, C., Graversen, E. K., \& Pedersen, H. S. (2015). Researcher mobility and sector career choices among doctorate holders. Research Evaluation, 24, 171-180. https://doi.org/10.1093/reseval/rvv004 


\section{Doctorate Holders' Transition to Industry: Networks as a Mechanism?

Brennan, M. (1998). Struggles over the definition and practice of the educational doctorate in Australia. The Australian Educational Researcher, 25(1), 71-89.

Bøgelund, P. (2015). How supervisors perceive PhD supervision-And how they practice it. International Journal of Doctoral Studies, 10(1), 39-55.

Calvó-Armengol, A., \& Zenou, Y. (2005). Job matching, social network and word-of-mouth communication. Journal of Urban Economics, 57(3), 500-522. https://doi.org/10.1016/j.jue.2005.01.001

Cañibano, C., Woolley, R., Iversen, E. J., Hinze, S., Hornbostel, S., \& Tesch, J. (2018). A conceptual framework for studying science research careers. Journal of Technology Transfer, 1-29. https://doi.org/10.1007/s10961-018-9659-3

CEDEFOP (2016). Future skill needs in Europe: critical labour force trends. Luxembourg: Publications Office. CEDEFOP research paper; No 59.

Corcoran, J., \& Faggian, A. (2017). Graduate migration and regional development: an international perspective. (J. Corcoran \& A. Faggian, Eds.). Edward Elgar Publishing.

Cruz-Castro, L., \& Sanz-Menéndez, L. (2005). The employment of PhDs in firms: trajectories, mobility and innovation. Research Evaluation, 14(1), 57-69.

De la Harpe, B., Radloff, A., \& Wyber, J. (2000) Quality and Generic (Professional) Skills, Quality in Higher Education, 6:3, 231-243, https://doi.org/10.1080/13538320020005972

Doeringer, P. and Piore, M. (1971). Internal Labour Markets and Manpower Analysis, Heath, Lexington, Mass.

Drejer, I. Holm, J., \& Østergaard, C.R. (2016). Where do they go? A comparative analysis of the career paths of $\mathrm{PhD}$ graduates from humanities and social sciences at Aalborg University, 1994-2012 


\section{Doctorate Holders' Transition to Industry: Networks as a Mechanism?

Eisenhardt, K. M., \& Graebner, M. E. (2007). Theory building from cases: Opportunities and challenges. Academy of management journal, 50(1), 25-32.

Etmanski, B., Walters, D., \& Zarifa, D. (2017). Not What I Expected: Early Career Prospects of Doctoral Graduates in Academia. Canadian Journal of Higher Education, 47(3), 152169.

European Commision (n.d.). The Bologna Process and the European Higher Education Area. $\quad$ https://ec.europa.eu/education/policies/higher-education/bologna-processand-european-higher-education-area en

EHEA. (2018). The framework of qualifications for the European Higher Education.

EHEA (n.d.). Full Members. http://ehea.info/page-full members

Gaeta, G. L., Lubrano Lavadera, G., \& Pastore, F. (2016). Much Ado About Nothing? The Wage Effect of Holding a Ph.D. Degree But Not a Ph.D. Job Position (IZA Discussion Papers).

Granovetter, M. S. (1974). Getting a job : a study of contacts and careers. University of Chicago Press.

Golde, C. M. (2005). The role of the department and discipline in doctoral student attrition: Lessons from four departments. The Journal of Higher Education, 76 (6), pp. 669-700.

Green, F., \& McIntosh, S. (2007). Is there a genuine under-utilization of skills amongst the $\begin{array}{llll}\text { over-qualified? } & \text { Applied }\end{array}$ https://doi.org/10.1080/00036840500427700

Hager, P., Holland, S., \& Beckett, D. (2002). Enhancing the learning and employability of graduates: The role of generic skills. B-Hert Position Paper, 9. 


\section{Doctorate Holders' Transition to Industry: Networks as a Mechanism?

Hancock, S., and Walsh, E. (2014). Beyond Knowledge and Skills: Rethinking the Development of Professional Identity During the STEM Doctorate. Studies in Higher Education. 41 (1), pp. 37-50.

Hayter, C. S., \& Parker, M. A. (2019). Factors that influence the transition of university postdocs to non-academic scientific careers: An exploratory study. Research Policy, $48(3), 556-570$.

Herrera, L., \& Nieto, M. (2013). Recruitment of PhD researchers by firms. In 35th DRUID Celebration Conference, Barcelona, Spain. Google Scholar.

Hultgren, Anna Kristina; Gregersen, Frans and Thøgersen, Jacob (2014). English in Nordic universities: ideologies and practices. In: Hultgren, Anna Kristina; Gregersen, Frans and Thøgersen, Jacob eds. English in Nordic Universities: Ideologies and Practices. Studies in World Language Problems (5). Amsterdam: John Benjamins, pp. 1-26.

Iammarino, S., \& Marinelli, E. (2015). Education-Job (Mis)Match and Interregional Migration: Italian University Graduates' Transition to Work. Regional Studies, 49(5), 866-882. https://doi.org/10.1080/00343404.2014.965135

Jackson, D., \& Michelson, G. (2015). Factors influencing the employment of Australian PhD graduates. Studies in Higher Education, 40(9), 1660-1678.

Kyvik, S., \& Olsen, T. B. (2012). The relevance of doctoral training in different labour markets. Journal of Education and Work, 25(2), 205-224. https://doi.org/10.1080/13639080.2010.538376

Lam, A. (2007). Knowledge Networks and Careers: Academic Scientists in IndustryUniversity Links*. Journal of Management Studies, 44(6), 993-1016. https://doi.org/10.1111/j.1467-6486.2007.00696.x 


\section{Doctorate Holders' Transition to Industry: Networks as a Mechanism?

Lam, A. (2011). University-industry collaboration: careers and knowledge governance in hybrid organizational space, International Journal of Strategic Business Alliances, 2 (1), $135-145$.

Larson, R. C., Ghaffarzadegan, N., \& Xue, Y. (2014). Too many PhD graduates or too few academic job openings: the basic reproductive number R0 in academia. Systems research and behavioral science, 31(6), 745-750.

LERU (2016). Maintaining a quality culture in doctoral education: At researchintensive universities. https://www.leru.org/publications/maintaining-aquality-culture-indoctoral-education-at-research-intensive-universities\#

Lisbon European Council. (2000). Presidency Conclusions.

Maki, P. L., \& Borkowski, N. A. (2006). The Assessment of Doctoral Education. Emerging Criteria and New Models for Improving Outcomes. Stirling, Virginia: Stylus.

Manathunga, C., Pitt, R., \& Critchley, C. (2009). Graduate attribute development and employment outcomes: Tracking PhD graduates. Assessment \& Evaluation in Higher Education, 34(1), 91-103.

Mangematin, V. (2000). PhD job market: professional trajectories and incentives during the PhD. Research Policy, 29 (6), pp. 741-756.

Manwaring, T. (1984). The extended internal labour market, Cambridge Journal of Economics, 8, 161-187.

March, J. G. (1991). Exploration and exploitation in organizational learning. Organization science, 2(1), 71-87.

Mcgowan, M. A., \& Andrews, D. (2015). The future of productivity: Skill mismatch and public policy in OECD countries. OECD Economics Department Working Papers. https://doi.org/http://dx.doi.org/10.1787/5js1pzw9lnwk-en 


\section{Doctorate Holders' Transition to Industry: Networks as a Mechanism?

McGowan, M. A., \& Andrews, D. (2017). Skills mismatch, productivity and policies: Evidence from the second wave of PIAAC (OECD Economics Department Working Papers).

McGuinness, S., \& Byrne, D. (2015). Born abroad and educated here: examining the impacts of education and skill mismatch among immigrant graduates in Europe. IZA Journal of Migration, 4(1). https://doi.org/10.1186/s40176-015-0039-6

National Science Foundation. (2012). Science and Engineering Labor Force. In Science and Engineering Indicators 2012 (pp. 1-66).

Neumann, R., \& Tan, K. K. (2011). From PhD to initial employment: the doctorate in a knowledge economy. Studies in Higher Education, 36(5), 601-614. https://doi.org/10.1080/03075079.2011.594596

OECD. (2016). OECD Science, Technology and Innovation Outlook 2016 (OECD Science, Technology and Innovation Outlook). OECD. https://doi.org/10.1787/sti in outlook$\underline{2016-e n}$

Perkmann, M., Tartari, V., McKelvey, M., Autio, E., Broström, A., D’Este, P., ... Sobrero, M. (2013). Academic engagement and commercialisation: A review of the literature on university-industry relations. Research Policy, 42, 423-442. https://doi.org/10.1016/j.respol.2012.09.007

Roberts, A. G. (2018). Industry and PhD engagement programs: inspiring collaboration and driving knowledge exchange. Perspectives: Policy and Practice in Higher Education, 22(4), 115-123.

Sauermann, H., \& Roach, M. (2012). Science PhD career preferences: Levels, changes, and $\begin{array}{lllll}\text { advisor encouragement. } & \text { PLOS }\end{array}$ https://doi.org/10.1371/journal.pone.0036307

Sinche, M., Layton, R. L., Brandt, P. D., O'Connell, A. B., Hall, J. D., Freeman, A. M., ... Brennwald, P. J. (2017). An evidence-based evaluation of transferrable skills and job 


\section{Doctorate Holders' Transition to Industry: Networks as a Mechanism? \\ Cases from Norway, Sweden and the UK}

satisfaction for science PhDs. PloS One, 12(9), e0185023. https://doi.org/10.1371/journal.pone.0185023

The Group of Eight. (2013). The Changing PhD. https://go8.edu.au/files/docs/thechanging-phd final.pdf

Thune, T. (2009). Doctoral students on the university-industry interface: a review of the literature. Higher Education, 58(5), 637. https://doi.org/10.1007/s10734-009-9214-0

Thune, T., Kyvik, S., Sörlin, S., Olsen, T. B., Vabø, A., \& Tømte, C. (2012). PhD education in a knowledge society: An evaluation of PhD education in Norway.

Vitae (2010). Researcher development framework. https://www.vitae.ac.uk/vitaepublications/rdf-related/researcher-development-framework-rdf-vitae.pdf

Wallgren, L., \& Dahlgren, L. O. (2005). Doctoral education as social practice for knowledge development: Conditions and demands encountered by industry PhD students. Industry and Higher Education, 196), 433-443.

Wallgren, L., \& Dahlgren, L. O. (2007). Industrial doctoral students as brokers between industry and academia: Factors affecting their trajectories, learning at the boundaries and identity development. Industry and Higher Education, 21(3), 195-210.

Yin, R. (1984). Case study research. Beverly Hills.

\section{Appendlx}

\section{Interview guide}

\begin{tabular}{|l|l|l|}
\hline Theme & Question & Purpose \\
\hline Demographics & $\begin{array}{l}\text { Age } \\
\text { The time when the PhD was completed } \\
\text { Field of study/research } \\
\text { Is present work related to field of study? }\end{array}$ & To understand the background \\
\hline Current job & $\begin{array}{l}\text { Describe in a few words your current job } \\
\text { Is there any link with your PhD? }\end{array}$ & To understand the background \\
\hline
\end{tabular}




\section{Doctorate Holders' Transition to Industry: Networks as a Mechanism?

\begin{tabular}{|c|c|c|}
\hline & $\begin{array}{l}\text { Are your PhD studies useful for your current job? } \\
\text { How? } \\
\text { Was your PhD an industrial PhD? } \\
\text { Do you speak the local language? }\end{array}$ & \\
\hline \multirow[t]{4}{*}{$\begin{array}{l}\text { Path to } \\
\text { industry }\end{array}$} & $\begin{array}{l}\text { When did you graduate }(\mathrm{PhD}) \text { ? } \\
\text { When did you leave academia for industry? }\end{array}$ & $\begin{array}{l}\text { Historical footprints could have } \\
\text { an effect on a person's decisions }\end{array}$ \\
\hline & $\begin{array}{l}\text { Have you always wanted to work in industry? } \\
\text { - This kind of industry? Why? } \\
\text { - If changed? Why? (who and what } \\
\text { influenced it? How did the influence } \\
\text { happen?) }\end{array}$ & $\begin{array}{l}\text { To see if will / inspiration comes } \\
\text { from someone in particular (thus } \\
\text { from network) or not }\end{array}$ \\
\hline & $\begin{array}{l}\text { Did you work in industry prior to your Phd? } \\
\text { - Have they returned to the same or similar } \\
\text { industry? } \\
\text { - No - What/who could have influenced a } \\
\text { change in industry? } \\
\text { - Yes- How has the PhD influenced your } \\
\text { work now that you are more educated? }\end{array}$ & $\begin{array}{l}\text { To see if network was built prior } \\
\text { to the } \mathrm{PhD}\end{array}$ \\
\hline & $\begin{array}{l}\text { How did you find your job (the one of } \\
\text { transition)? }\end{array}$ & \\
\hline \multirow[t]{4}{*}{$\begin{array}{l}\text { Prior } \\
\text { connections }\end{array}$} & Did your job exist or was it created for you? & $\begin{array}{l}\text { Influence of network on landing } \\
\text { industry employment } \\
\text { (connections to people, places } \\
\text { and institutions) }\end{array}$ \\
\hline & Were you referred to this job? & \\
\hline & $\begin{array}{l}\text { Did you know anyone in your job prior to the } \\
\text { appointment? How? Who? } \\
\text { - Did you know this person during your } \\
\text { Phd? }\end{array}$ & \\
\hline & $\begin{array}{l}\text { Did your PhD supervisor (or any academic) play } \\
\text { a role in this transition? }\end{array}$ & \\
\hline \multirow[t]{2}{*}{ Feedback loop } & Would you want to go back to Academia? Why? & $\begin{array}{l}\text { To get the interviewee to be } \\
\text { reflective, assess influences, etc. }\end{array}$ \\
\hline & $\begin{array}{l}\text { Who in academia have you remained in contact } \\
\text { with? (why?) }\end{array}$ & \\
\hline
\end{tabular}




\section{Doctorate Holders' Transition to Industry: Networks as a Mechanism? \\ Cases from Norway, Sweden and the UK}

\begin{tabular}{|l|l|l|}
\hline \multirow{2}{*}{ Network } & $\begin{array}{l}\text { Have you built your network during your PhD } \\
\text { studies or before? } \\
\text { What type of network? (academia, industry) }\end{array}$ & $\begin{array}{l}\text { To understand the background } \\
\text { + To get the interviewee to be } \\
\text { reflective, assess influences, etc. }\end{array}$ \\
\cline { 2 - 3 } & Is your network the same as your supervisor's? & \\
\cline { 2 - 3 } & $\begin{array}{l}\text { Do you still use the network you built during } \\
\text { your PhD studies? }\end{array}$ & \\
\cline { 2 - 3 } & $\begin{array}{l}\text { Do you think it could be useful to find a job? } \\
\text { How? }\end{array}$ & \\
\hline Region & $\begin{array}{l}\text { Why did you choose [university] for your PhD? } \\
\text { + To get the interviewee to be } \\
\text { reflective, assess influences, etc. }\end{array}$ & \\
\cline { 2 - 3 } & $\begin{array}{l}\text { Why did you leave [stay in] the region after the } \\
\text { PhD? }\end{array}$ & $\begin{array}{l}\text { Would you have liked to stay in [leave] the } \\
\text { region? }\end{array}$ \\
\cline { 2 - 3 } & $\begin{array}{l}\text { Were there job opportunities for you in the } \\
\text { region? }\end{array}$ & \\
\cline { 2 - 3 } & $\begin{array}{l}\text { If you had been referred to a position in the } \\
\text { region, would you have accepted it instead of } \\
\text { your current job? }\end{array}$ & \\
\hline
\end{tabular}

\section{Perceived relevance of PhD studies to industry jobs}

\begin{tabular}{|l|l|l|l|}
\hline $\begin{array}{l}\text { Variants } \\
\text { observed }\end{array}$ & $\begin{array}{l}\text { Relevance of PhD to } \\
\text { job }\end{array}$ & Area of relevance & $\begin{array}{l}\text { Required PhD } \\
\text { degree }\end{array}$ \\
\hline 1 & Yes & Same research field & Yes \\
\hline 2 & Yes & Same research field & No \\
\hline 3 & Yes & Similar/related research field & Yes \\
\hline 4 & Yes & Similar/related research field & No \\
\hline 5 & Yes & $\begin{array}{l}\text { Different research field } \\
-\quad \text { Skills acquired from PhD relevant }\end{array}$ & No \\
\hline
\end{tabular}

